\title{
Effect of Maize Stover Application as Soil Mulch on Yield of Arabica coffee (Coffee arabica L., Rubiaceae) at Western Hararghe Zone, Eastern Ethiopia
}

\author{
Zelalem Bekeko ${ }^{1}$ \\ ${ }^{1}$ Department of Plant Sciences, Haramaya University Chiro Campus, Chiro, Ethiopia \\ Correspondence: Zelalem Bekeko, Department of Plant Sciences, Haramaya University Chiro Campus, Po box \\ 335, Chiro, Ethiopia. Tel: 251-911-810-622. E-mail: zelalembekeko@yahoo.com
}

Received: December 14, 2012 Accepted: March 18, 2013 Online Published: March 20, 2013

doi:10.5539/sar.v2n3p15 URL: http://dx.doi.org/10.5539/sar.v2n3p15

\begin{abstract}
An experiment was conducted during the dry seasons in western Hararghe Zone, Eastern Ethiopia at the Haramaya University Chiro Campus to determine the effect of maize stover as soil mulch on yield of Arabica coffee. Five levels of maize stover as soil mulch at a rate of: $0 \mathrm{t} / \mathrm{ha}, 2 \mathrm{t} / \mathrm{ha}, 4 \mathrm{t} / \mathrm{ha}, 6 \mathrm{t} / \mathrm{ha}$ and $8 \mathrm{t} / \mathrm{ha}$ were applied in randomized complete block design with four replications from 2008 to 2011. Yield data was recorded during specific phenological stage of the plant. Result from the analysis of variance from the application of maize stover as soil mulch over years showed the presence of significant difference among treatments on bean yield of Arabica coffee. The highest bean yield $(1070 \mathrm{~kg} / \mathrm{ha})$ and the lowest bean yield $(520 \mathrm{~kg} / \mathrm{ha})$ were noted at 8 tons/ha and 0 ton/ha, respectively. Similarly, the pooled analysis of variance over seasons corroborated that the effect of maize stover as a soil mulch at a rate of $6 \mathrm{t} / \mathrm{ha}$ and $8 \mathrm{t} / \mathrm{ha}$ showed the presence of no significant difference on bean yield of coffee $(\mathrm{p}<0.05)$. The result of the present study also elucidated that, the unmulched control plots had the lowest coffee bean yield. While application of 8 tons/ha of maize stover as a soil mulch significantly increased coffee yield both in 2010 and 2011 cropping seasons. Therefore, on the basis of these results, it can be concluded that applying maize stover as soil mulch during the dry seasons at west Hararghe can help to sustain Arabica coffee production. Thus, it is recommended that application of 8tons/ha maize stover as soil mulch can significantly increase the yield of Arabica coffee and sustains its productivity over years.
\end{abstract}

Keywords: maize stover, arabica coffee, soil fertility, mulch, coffee bean yield, western Hararghe

\section{Introduction}

Ethiopia is the third largest Arabica coffee (Coffee arabica L.) producer in the world (IOC, 2010). In the world Coffee is the second most traded commodity next to petroleum and the most widely consumed beverage worldwide (Vega, 2008). Coffee from the eastern part of Ethiopia, Hararghe areas is known for its Mocha flavor that fetches the highest premium value on the world market. However, coffee production in this region is affected by lack of soil moisture during the dry seasons and poor soil fertility. In Ethiopia coffee is still a major contributor to Ethiopian economy and it plays a key role in the livelihood of about 1.5 million of coffee growing households in this country. Over 15 million people depend directly or indirectly on coffee being involved in production, processing and marketing activities (Petit, 2007; Labouisse et al., 2008). In Ethiopia coffee grows in diverse agro ecologies ranging from 1000 m.a.s.l to over 2000 m.a.s.l in its native area under the forest canopy (Labouisse et al., 2008).

Ecologically sustainable coffee production is certainly possible by applying best practices of agronomy, crop protection and post-harvest processing. These include soil conservation measures with or without shade trees, applying organic and inorganic fertilizers to maintain optimum soil quality and crop nutrient levels, planting of disease resistant varieties and applying IPM (integrated pest management) to reduce crop losses due to biotic stress factors, and the use of novel processing equipment. Mitchell (1988) reported that without mulch or other sources of organic matter, significant yield responses to N, P and K fertilizers are common, but such coffee production systems may not be sustainable in the long term because of a gradual decline in soil quality to be expected for most soil types. Yunianto (1986) also indicated use of mulch help in reducing over bearing and dieback in Arabica coffee and sustains its biological productivity for longer period of time. 
The application of mulch on coffee soils is also known to help in maintaining soil temperature regulation and reserving the soil moisture by decreasing evapo transpiration from the surface soil which contributes to generation of greater number of fruits per node and nodes per lateral branches produced under full-sun responsible for the greater yield of coffee. But this was contrary to other results of (Wintgens, 2004; Morais et al., 2006). However, some other reports have suggested that coffee plants that receive more sunlight with judicious level of soil mulch can produce a greater number of flowers (Beer et al., 1987; Vaast et al., 2006) This is because of the more number of nodes formed per lateral or more flower buds existing at each node (Wintgens, 2004; Cannel, 1975).

In Hararghe areas coffee is grown without shades, thus it is highly vulnerable to over bearing, dieback and loss of soil moisture which strongly affect productivity of coffee beans. Thus, the use of mulch can contribute in sustaining coffee production through enhancing the biological productivity of the coffee tree. The national average yield of coffee in Ethiopia is less than $700 \mathrm{~kg} / \mathrm{ha}$ as compared to other African countries and the world average yield which is more than $1200 \mathrm{~kg} / \mathrm{ha}$ (Labouisse et al., 2007; Campanha et al., 1982; Canell et al., 1985). This lower yield is attributed to both biotic and abiotic factors. Poor soil fertility management, soil moisture deficit, CBD (coffee berry disease), coffee wilt disease and insect pests are some of the factors contributing to lower yield of Arabica coffee in Ethiopia (Wassu et al., 2004; Damenu, 2008).

In the highlands of Hararghe coffee is grown as garden plantation being intercropped with different crops such as sweet potato, Chat (Chata edulis), banana and some other fruit crops (Damenu, 2008). Coffee production in this region is also affected by poor soil moisture during the dry seasons, poor soil fertility, CBD and the expansion of Chat plantation replacing coffee plantations. Coffee from this region is known for its Mocha flavor that fetches the highest premium value on the world market (Damenu, 2008). Various attempts have been made to determine the importance of numerous factors that affect growth and bean quality in coffee agro ecosystems, including climatic conditions, shade management, fertilization regimes, mulching and adequate pruning in different coffee growing regions of the world including Ethiopia (Wintgens, 2004; Steiman, 2008; Bosselmann et al., 2009; valos-Sartorio \& Blackman, 2010). For example, some work done by Beer (1987) and DaMatta (2004) to document the relationship between shade and coffee yield found positive effects in suboptimal locations, whereas Soto-Pinto et al. (2000) found negative effects when shade level was above 50\%. Siles et al. (2010) found that high shade (60 to $80 \%$ ) coffee flowers equally well to the medium-shade (30 to 50\%) in low-input coffee farms of Chiapas, Mexico. Results differ because the environmental factors and the coffee varieties examined vary among the studies, and issues of exact environmental needs are difficult to quantify because of the variation (Carr, 2001).

Optimal shade levels are likely to be below $50 \%$, especially for coffee that receives fertilization or supplemental irrigation. What is unknown is whether the tradeoff of yield with bean size, flavor profile, or other aspects of quality, that can occur with shade results in a net benefit to the producer. Litter fall from shade trees serve as soil mulch and contribute in yield sustenance. However, as compared to studies made on the use of shade trees, the role of mulch in coffee production under unshaded condition has not been well studied in many coffee producing countries including Ethiopia.

In unshaded coffee, mulch from grasses, wheat straw and maize stover helps to control soil erosion and weeds, preserve soil moisture and is also an important source of organic matter and nutrients (Mitchell, 1988; Anderson et al., 1990; Youkhana et al., 2009). For instance, the practice of applying annually large quantities (5 to10 $t / h a)$ of mulch cut from elephant (Napier) grass (Pennisetum purpureum) on a coffee plantation in Kenya adds large amounts of plant nutrients to the soil, $\mathrm{K}$ in particular $10 \mathrm{t} / \mathrm{ha}$ of mulch from elephant grass would contain $150 \mathrm{~kg}$ $\mathrm{N}, 26 \mathrm{~kg}$ P and $350 \mathrm{~kg} \mathrm{~K}$ (Njoroge, 2001) but from natural grasses or maize stover 140-200 kg N, 13-15 kg P and 88-160 kg K could be obtained (Njoroge, 2001; Babbar et al., 1995).

However, smallholder coffee farmers in eastern parts of Ethiopia usually have no access to such large quantities of mulch material and instead prefer to feed whatever is available to their livestock rather than applying to their farm lands (Zelalem, 2012). Mulching of unshaded coffee is not much practiced in most other coffee producing countries including Ethiopia (Kufa et al., 2001). Here again, it is fairly realistic that more mulch is being applied where yields are higher: 10 t/ha mulch applied annually (nutrient input of $150 \mathrm{kgN}, 26 \mathrm{~kg} \mathrm{P}$ and $350 \mathrm{~kg} \mathrm{~K}$ ) to coffee yielding $2 \mathrm{t} / \mathrm{ha}^{-1}$ green beans and $5 \mathrm{t}$ mulch at half the yield level (Njoroge, 2001). Without mulch or other sources of organic matter, significant yield responses to N, P and K fertilizers are common, but such coffee production systems may not be sustainable in the long term because of a gradual decline in soil quality to be expected for most soil types (Mitchell, 1988; Wilson, 1985). 
Western Hararghe is one of the most drought prone areas of the Oromia Regional State, eastern Ethiopia (Damenu, 2008). As a result of this coffee yield is strongly influenced by lack of soil moisture during growth, flowering, fruit setting, bean synthesis and expansion (Damenu, 2008). Soil mulch significantly contributes to alleviate these stresses. However, local farmers from the region use sorghum and maize stover for animal feed, fuel wood and fencing which leads to poor soil organic matter build up in the zone (Ararsa, 2012). As a result the soil from this region is suffering from soil erosion, nutrient leaching and poor soil moisture regime leading to poor crop productivity including Arabica coffee (Coffee arabica L.).

The use of maize stover as soil mulch in sustaining coffee production and productivity in this region has never been investigated before. Therefore, the objective of this study was to determine the effect of maize stover as soil mulch on yield of Arabica coffee at Chiro, Western Hararghe Zone, Eastern Ethiopia.

\subsection{Description of the Study Area}

West Hararghe is located between $7^{\circ} 55^{\prime} \mathrm{N}$ to $9^{\circ} 33^{\prime} \mathrm{N}$ latitude and $40^{\circ} 10^{\prime} \mathrm{E}$ to $41^{\circ} 39^{\prime} \mathrm{E}$ longitude. The major crops grown in the study area are sorghum, maize, chat, field beans, potato and tef (Eragrostis abyssinica). The area is characterized by Charcher Highlands having undulating slopes and mountainous in topography. The mean annual rainfall ranges from 850 to $1200 \mathrm{~mm} /$ year with minimum and maximum temperatures of $12{ }^{\circ} \mathrm{C}$ and $27^{\circ} \mathrm{C}$, respectively.

\section{Materials and Methods}

\subsection{Experimental Procedures}

The already existing coffee plantation in Chiro Campus, Haramaya University, was used as a test plant. A plot size of $6 \mathrm{~m}$ length by $5 \mathrm{~m}$ width with three rows per plot was used. Spacing was $2 \mathrm{~m}$ and $1.8 \mathrm{~m}$ between rows and plants, respectively. Urea at a rate of $150 \mathrm{~kg} / \mathrm{ha}$ was applied to each experimental plot on 15 June 2008, 10 June 2009, 15 June 2010 and 15 Jone 2011. Maize stover was harvested at the physiological maturity of maize and chopped at a size of $75 \mathrm{~cm}$ long and weighed using a spring balance to determine the amount of mulch material required by each plot. Five levels of maize stover as soil mulch at a rate of: $0 \mathrm{t} / \mathrm{ha}, 2 \mathrm{t} / \mathrm{ha}, 4 \mathrm{t} / \mathrm{ha}, 6 \mathrm{t} / \mathrm{ha}$ and $8 \mathrm{t} / \mathrm{ha}$ was applied to each plot at the end of the main rainy season for each year (after mid- September in all years). Treatments were applied in a randomized complete block design with four replications in 2008 to 2011 .

At maturity, dried coffee beans were collected from each plot and manually hulled to get clean coffee. The recorded yield per plot was converted to yield per hectare. An area of $15 \mathrm{~m}^{2}$, corresponding to 4 plants in the central two rows, were picked immediately after physiological maturity for bean yield. During harvest, border plants at the ends of each row were excluded to avoid border effects. Bean yield of coffee (GY $\left.\mathrm{t} \mathrm{ha}{ }^{-1}\right)$ was determined using picked coffee beans and adjusted to $12 \%$ moisture (Labouise et al., 2008).

\subsection{Statistical Analyses}

The data recorded in this study were subjected to statistical analysis using the statistical program SAS (1990) version 9.0. Analyses of variance were carried out using MSTATC soft ware. Significant differences between and /or among treatments were delineated by Least Significant Differences (LSD).

\section{Results}

Result from the analysis of variance on mean yield of coffee beans over the four seasons showed the existence of significant differences among treatments (Table 1 and Table 3). Mean bean yield ranged from $520 \mathrm{~kg} / \mathrm{ha}$ to 1070 $\mathrm{kg} / \mathrm{ha}$ over four years. The highest mean yield $1070 \mathrm{~kg} / \mathrm{ha}$ was observed in 2009 and the poorest yield $(520 \mathrm{~kg} / \mathrm{ha})$ was noted in 2011. The over all Result from the pooled analysis of variance on bean yield of Arabica coffee from the present study reveled the presence of significant difference $(\mathrm{P}<0.05)$ among treatment over the seasons (Table 1 and Table 2). This study also indicated application of maize stover as soil mulch on coffee trees increased the bean yield of coffee trees over years and significantly reduced weed infestation and increased soil moisture reserve. The result also showed the existence of no significant difference between $6 \mathrm{t} / \mathrm{ha}$ and $8 \mathrm{t} / \mathrm{ha}$ on coffee bean yield. Similarly application of maize stover at a rate of $2 \mathrm{t} / \mathrm{ha}$ and the unmulched plots showed no significant differences on bean yield of coffee trees. However, slight variations were observed in weed suppression effect and soil moisture reservation. 
Table 1. The effect of maize stover as soil mulch on yield of Arabica coffee $(\mathrm{kg} / \mathrm{ha})$ clean coffee (mean values) at Chiro, Western Hararghe 2008 to 2011 cropping seasons

\begin{tabular}{lccccc}
\hline \multicolumn{7}{c}{ Coffee bean yield (kg/ha) } \\
Treatment & $1^{\text {st }}$ replication & $2^{\text {nd }}$ replication & $3^{\text {rd }}$ replication & $4^{\text {th }}$ replication & Total \\
\hline $0 \mathrm{t} / \mathrm{ha}$ & 564 & 487 & 545 & 526 & 2122 \\
$2 \mathrm{t} / \mathrm{ha}$ & 547 & 523 & 520 & 553 & 2143 \\
$4 \mathrm{t} / \mathrm{ha}$ & 618 & 642 & 653 & 629 & 2542 \\
$6 \mathrm{t} / \mathrm{ha}$ & 961 & 979 & 943 & 984 & 3867 \\
$8 \mathrm{t} / \mathrm{ha}$ & 1062 & 1054 & 1070 & 1063 & 4249 \\
Total & 3752 & 3685 & 3731 & 3755 & 14923 \\
$\mathrm{LSD}=0.05$ & 122.06 & & & & \\
$\mathrm{CV}(\%)$ & 11.89 & & & & \\
\hline
\end{tabular}

Table 2. Analysis of Variance (mean values) for the effect of maize stover applied as soil mulch on Arabica coffee yield (kg/ha) at Chiro, Western Hararghe from 2008 to 2011

\begin{tabular}{lccccc}
\hline Sources of variation & DF & \multicolumn{1}{c}{$\mathrm{SS}$} & \multicolumn{1}{c}{$\mathrm{MS}$} & $\mathrm{F}_{\text {cal }}$ & $\mathrm{F}_{\text {tab }}$ \\
\hline Treatment & 4 & 339680.25 & 84920.06 & & \\
Replication & 3 & 626.55 & 208.85 & & \\
Error & 12 & 75323.75 & 6276.979 & $13.53^{*}$ & 3.26 \\
total & 19 & 415630.55 & & & \\
$\mathrm{CV}(\%)$ & & & & 11.89 & \\
$\mathrm{LSD}=0.05$ & & & & 122.06 & \\
& & & & &
\end{tabular}

*significant at $\alpha=0.05$.

Table 3. Mean Separation (Duncan's Multiple Range Test) for the effect of maize stover applied as soil mulch on Arabica coffee yield (kg/ha) at Chiro, Western Hararghe from 2008 to 2011

\begin{tabular}{cccccc}
\hline & 530.5 & 535.75 & 635.5 & 966.75 & 1062.25 \\
\hline 530.5 & 0 & $-5.25^{*}$ & $-105^{*}$ & $-436.25^{*}$ & $-531.75^{*}$ \\
535.75 & & 0 & $-99.75^{*}$ & $-431^{*}$ & $-526.50^{*}$ \\
635.5 & & & 0 & $-331.25^{*}$ & $-426.75^{*}$ \\
966.75 & & & & 0 & $-95.5^{*}$ \\
1062.25 & & & & & 0 \\
\hline
\end{tabular}

*significant at $\alpha=0.05$.

\section{Discussion}

In the present study bean yield of Arabica coffee at Chiro was significantly increased as the rate of maize stover application as soil mulch increased from $2 \mathrm{t} / \mathrm{ha}$ to $8 \mathrm{t} / \mathrm{ha}$ (Table 1$)$. The highest bean yield $(1070 \mathrm{~kg} / \mathrm{ha})$ was obtained at $8 \mathrm{t} / \mathrm{ha}$ followed by $6 \mathrm{t} / \mathrm{ha}$ (Table1 and Table 3). Application of maize stover contributed a yield advantage of $550 \mathrm{~kg} / \mathrm{ha}$ over the unmulched plots. This can be owing to the effect of the stover in reducing soil moisture loss, maintainace of soil temperature and addition of nutrients. Njoroge et al. (2001) reported that the bean yield of Arabica coffee from Kenya increased from $1.2 \mathrm{t} / \mathrm{ha}$ to over $2 \mathrm{t} / \mathrm{ha}$ when 10t/ha mulch is applied. Therefore, the present finding is in agreement with this report. But a significant difference in coffee yield was observed during the experimental seasons over years indicating the poorest yield record in 2009 and 2011. This might be due to variation in environmental differences among the growing seasons, the response of the coffee trees to the environment and G x E (gene by environment interaction). In addition the application of $8 \mathrm{t} / \mathrm{ha}$ 
increased bean yield by $550 \mathrm{~kg} / \mathrm{ha}$ as compared to the control treatment implying use of maize stover as soil mulch helps to boost coffee productivity which is also in agreement with the reports by Njoroge et al. (2001) who stated application of Napier grass increases bean yield of Arabica coffee under moisture deficit areas.

In Kenya according to the nutrient content data of various mulches and manures provided by Njoroge (2001) $10 \mathrm{t}$ of mulch from elephant grass would contain $150 \mathrm{~kg} \mathrm{~N}, 26 \mathrm{~kg}$ P and $350 \mathrm{~kg} \mathrm{~K}$, but from natural grasses or maize stover $140-200 \mathrm{~kg} \mathrm{~N}, 13-15 \mathrm{~kg}$ P and 88-160 kg K were obtained. In the present study Nitrogen composition in the soil remained unchanged over the four years (Appendix Table 1). This might be due to the increase in soil organic carbon percentage. However, the level available $\mathrm{P}$ increased in the treated plots suggesting the existence of consistent finding with the reports of Njoroge (2001) in which mulch from grasses contributed an additional value of $26 \mathrm{~kg} / \mathrm{ha} \mathrm{P}$ (Appendix Table 1). Therefore, the present finding is in agreement with these reports. Hence the application of maize stover at the rate of $8 \mathrm{t} / \mathrm{ha}$ resulted in highest bean yield, which was significantly higher than maize stover applied at the rates of 0,2 and $4 \mathrm{t} / \mathrm{ha}$, while it was statistically at par with bean yield obtained at 6 t/ha (Table 2 and Table 3 ).

\section{Conclusion}

From this finding it can be concluded that applying maize stover as soil mulch during the dry seasons in west Hararghe can help to sustain Arabica coffee production. Thus, it is recommended that application of 8tons/ha maize stover as soil mulch can significantly increase the yield of Arabica coffee and sustain its productivity over years. In addition, laboratory and field trials need to be conducted on $\mathrm{C}$ : $\mathrm{N}$, nitrogen mineralization and its effect on soil microbial populations.

\section{Acknowledgements}

The author is grateful to the Ministry of Agriculture and Rural Development of the Federal Democratic Republic of Ethiopia, Chiro ATVET College for funding this research project, Professor Temam Hussein for his technical advice during the field experiment, Tedila Mulu, Genet Nigussie, Bacha Reda, and Tadesse Bedada for their assistance during the field data collection and Zimita Kidane in compiling and storing this data.

\section{References}

Anderson, J. M., \& Ingram, J. S. I. (1990). Tropical soil biology and fertility: A handbook of 434 methods. Wallingford, UK: CAB Int.

Ararsa, G. (2012). GIS based land suitability evaluation for sustainable agricultural development at Kuni (Sebale) watershed West Hararghe Zone, Oromia. M.Sc. thesis Mekele University, Ethiopia.

Babbar, L. I., \& Zak, D. R. (1995). Nitrogen loss from coffee agro ecosystems in Costa Rica: leaching and denitrification in the presence and absence of shade trees. Journal of Environmental Quality, 24, 227-233. http://dx.doi.org/10.2134/jeq1995.00472425002400020003x

Beer, J. W. (1987). Advantages, disadvantages and desirable characteristics of shade trees for coffee, cocoa and tea. Agroforestry Systems, 5, 3-13. http://dx.doi.org/10.1007/BF00046410

Bosselmann, A. S., Dons, K., Oberthur, T., Olsen, C. S., Raebild, A., \& Usma, H. (2009). The influence of shade trees on coffee quality in small holder coffee agro forestry systems in Southern Colombia. Agriculture, Ecosystems and Environment, 129, 253-260. http://dx.doi.org/10.1016/j.agee.2008.09.004

Cannell, M. G. R. (1975). Crop physiological aspects of coffee bean yield: a review. J Coffee Res., 5, 7-20.

Cannell, M. G. R. (1985). Physiology of the coffee crop. In M. N. Clifford \& K. C. Willson (Eds.), Coffee: Botany, Biochemistry and Production of Beans and Beverage, (pp. 108-124). London: Croom Helm.

Carr, M. V. (2001). The water relations and irrigation requirements of coffee. Exp. Agric., 37, 1-36. http://dx.doi.org/10.1017/S0014479701001090

Da Matta, F. M. (2004). Eco physiological constraints on the production of shaded and unshaded coffee: a review. Field Crops Research, 86, 92-114.

Damenu. (2008). Coffee production and marketing in Oromia. In coffee diversity and knowledge, Ethiopian Institute of Agricultural Research.

IOC. (2010). Coffee market report, Letter from the executive director.

Kufa, T., \& Shimber, T. (2001). Organic coffee production: hope for small-scale farmers in Ethiopia. Proceedings of the 19th International Scientific Colloquium on Coffee. Trieste, 14-18.

Labouisse, J. P., Belleachew, B., Kotecha, S., \& Bertrand, B. (2008). Current status of Coffee (Coffee Arabica) 
genetic resource in Ethiopia: Implication for conservation Genet. Resour. Crop Evol., 55, 1079-1093. http://dx.doi.org/10.1007/s10722-008-9361-7

Mitchell, H. W. (1988). Cultivation and harvesting of the arabica coffee tree. In R. J. Clarke \& R. Macrae (Eds.), In: Coffee, vol. 4 Agronomy (pp. 43-90). London: Elsevier Applied Science.

Morais, H., Caramori, P., Ribeiro, A. M., Gomes, J. C., \& Koguishi, M. S. (2006). Microclimatic characterization and productivity of coffee plants grown under shade of pigeon pea in Southern Brazil. Pesq. Agropec. Bras., 41(5), 763-770. http://dx.doi.org/10.1590/S0100-204X2006000500007

Njoroge, J. M. (2001). Advances in coffee agronomy. In Proceedings of the International Scientific Symposium on Coffee December 4, 2000, CBI-CCRI Bangalore India. pp. 104-119.

Perfecto, I., Vandermeer, J., Mas, A., \& Soto Pinto, L. (2005). Biodiversity, yield and shade coffee certification. Ecological Economics, 54, 435-446. http://dx.doi.org/10.1016/j.ecolecon.2004.10.009

Petit, N. (2007). Ethiopia's coffee sector: bitter or better future. J. Agrarian Change, 7, 225-263. http://dx.doi.org/10.1111/j.1471-0366.2007.00145.x

SAS Institute Inc. (1990). SAS/STAT user's guide (4th ed.). SAS Institute Inc, Cary, NC, USA.

Siles, P., Harmand, J., \& Vaast, P. (2010). Effects of Inga densiflora on the microclimate of coffee (Coffea arabica L.) and overall biomass under optimal growing conditions in Costa Rica. Agro forestry Systems, 78(3), 269-286. http://dx.doi.org/10.1007/s10457-009-9241-y

Soto-Pinto, L., Perfecto, I., Castillo-Hernandez, J., \& Caballero-Nieto, J. (2000). Shade effect on coffee production at the northern Tzeltal zone of the state of Chiapas, Mexico. Agriculture, Ecosystems \& Environment, 80, 61-69. http://dx.doi.org/10.1016/S0167-8809(00)00134-1

Vaast, P., Bertrand, B., Guyot, B., \& Genard, M. (2006). Fruit thinning and shade improve bean characteristics and beverage quality of coffee (Coffee arabica L.) under optimal conditions. Journal of the Science of Food and Agriculture, 86(2), 197-204. http://dx.doi.org/10.1002/jsfa.2338

Valos-Sartorio, B. A., \& Blackman, A. (2010). Agroforestry price supports as a conservation tool: Mexican shade coffee. Agroforestry Systems, 78, 169-183. http://dx.doi.org/10.1007/s10457-009-9248-4

Vega, F. E. (2008). The rise of coffee. AM. Sci., 96, 138-145. http://dx.doi.org/10.1511/2008.70.3640

Wassu, M., Bayetta, B., \& Harjit, S. (2004). Hetrosis and combining ability for yield and yield related trait in Arabica coffee. M.Sc. thesis Haramaya University, Ethiopia.

Wilson, K. C. (1985). Mineral nutrition and fertilizer needs. In M. N. Clifford \& K. C. Willson (Eds.), In Coffee: Botany, Biochemistry and Production of Beans and Beverage, (pp. 135-156). London: Croom Helm.

Wintgens, J. N. (2004). Coffee: Growing, Processing, Sustainable Production. WILEY-VCH Verlag GmbH \& Co. KGaA, Weinheim, p. 976.

Youkhana, A., \& Idol, T. (2009). Tree pruning mulch increases soil $\mathrm{C}$ and $\mathrm{N}$ in a shaded coffee agro ecosystem in Hawaii. Soil biology and Biochemistry, 41(12), 2527-534. http://dx.doi.org/10.1016/j.soilbio.2009.09.011

Yunianto, Y. D. (1986). Overbearing dieback on Arabica coffee. J. Pel. Parkebu, 2(2), 60-65.

Zelalem, B. (2012). Effect of Nitrogen and Phosphorus fertilizers on Some Soil Properties and Grain Yield of Maize (BH-140) at Chiro, Western Hararghe, Ethiopia. African Journal of Agricultural Research. (Submitted). 
Appendix 1. Effect of maize stover as soil mulch on some physical and chemical properties of soil 95 days after application at Chiro, Western Hararghe zone 2008 to 2011 cropping seasons (mean values)

\begin{tabular}{|c|c|c|c|c|c|c|c|c|c|c|c|c|c|}
\hline \multirow{2}{*}{$\begin{array}{l}\text { Soil Depth } \\
\text { (cm) }\end{array}$} & \multirow{2}{*}{ Horizon } & \multicolumn{3}{|c|}{ Particle size distribution (\%) } & \multirow{2}{*}{$\begin{array}{c}\text { Textural } \\
\text { class }\end{array}$} & \multirow{2}{*}{$\begin{array}{c}\text { PD } \\
g\left(\mathrm{~cm}^{3}\right)\end{array}$} & \multirow{2}{*}{$\begin{array}{c}\mathrm{BD} \\
\mathrm{g}\left(\mathrm{cm}^{3}\right)\end{array}$} & \multirow{2}{*}{$\begin{array}{l}\text { PS } \\
(\%)\end{array}$} & \multirow{2}{*}{$\mathrm{pH}$} & \multirow{2}{*}{$\begin{array}{l}\mathrm{OC} \\
(\%)\end{array}$} & \multirow{2}{*}{ Total N (\%) } & \multirow{2}{*}{$\begin{array}{l}\text { Av.P } \\
(\mathrm{ppm})\end{array}$} & \multirow{2}{*}{$\begin{array}{c}\mathrm{CEC} \\
\mathrm{Cmol} / \mathrm{kg}\end{array}$} \\
\hline & & Clay & Sand & Silt & & & & & & & & & \\
\hline $0-30$ & AP & 50 & 38 & 12 & clay & 2.38 & 0.99 & 67.2 & 7.61 & 5.03 & 0.44 & 59.3 & 68.7 \\
\hline $30-60$ & Bt1 & 18 & 56 & 26 & sand & 2.5 & 1.38 & 48.5 & 7.55 & 0.78 & 0.56 & 34.8 & - \\
\hline $60-90$ & $\mathrm{Bt} 2$ & 20 & 54 & 26 & sand & 2.5 & 1.34 & $52.0 *$ & 7.7 & 0.54 & 0.34 & 33.8 & - \\
\hline BAP & & & & & & & & 67.2 & & 5.03 & 0.44 & 37.9 & 59.71 \\
\hline $\mathrm{AP}$ & & & & & & & & $75.5^{*}$ & & $8.52 *$ & 0.43 & $59.3^{*}$ & $68.70^{*}$ \\
\hline
\end{tabular}

$P D=$ particle density, $B D=$ bulk density, $P S=$ percent porosity, $O C=$ organic carbon, $A V . P=$ available phosphorus, $C E C=$ cation exchange capacity, $\mathrm{BAP}=$ before application of maize sover, $\mathrm{AP}=$ after application of maize stover. 